\title{
Other Types of Meaning: Relationships between Round Barrows and Landscapes from 1500 bc-ac 1086
}

DOI:

$10.1017 /$ S0959774316000433

\section{Document Version}

Accepted author manuscript

Link to publication record in Manchester Research Explorer

\section{Citation for published version (APA):}

Cooper, A. (2016). Other Types of Meaning: Relationships between Round Barrows and Landscapes from 1500 bc-ac 1086. Cambridge Archaeological Journal, 26(4), 665-696. https://doi.org/10.1017/S0959774316000433

\section{Published in:}

Cambridge Archaeological Journal

\section{Citing this paper}

Please note that where the full-text provided on Manchester Research Explorer is the Author Accepted Manuscript or Proof version this may differ from the final Published version. If citing, it is advised that you check and use the publisher's definitive version.

\section{General rights}

Copyright and moral rights for the publications made accessible in the Research Explorer are retained by the authors and/or other copyright owners and it is a condition of accessing publications that users recognise and abide by the legal requirements associated with these rights.

\section{Takedown policy}

If you believe that this document breaches copyright please refer to the University of Manchester's Takedown Procedures [http://man.ac.uk/04Y6Bo] or contact uml.scholarlycommunications@manchester.ac.uk providing relevant details, so we can investigate your claim.

\section{OPEN ACCESS}




\section{Cambridge Archaeological Journal}

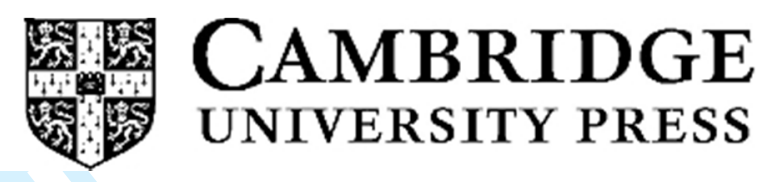

\section{Other types of meaning: relationships between round barrows and landscapes from 1500 BC-AD 1086}

\begin{tabular}{|r|l|}
\hline Journal: & Cambridge Archaeological Journal \\
\hline Manuscript ID & CAJ-AR-2016-0033.R1 \\
\hline Manuscript Type: & Article \\
\hline Date Submitted by the Author: & n/a \\
\hline Complete List of Authors: & Cooper, Anwen; University of Oxford, Institute of Archaeology \\
\hline Manuscript Keywords: & Round barrows, Landscape archaeology, Chronology, Grey literature \\
\hline
\end{tabular}

SCHOLARONE $^{\text {M }}$
Manuscripts 


\title{
Other types of meaning: relationships between round barrows and landscapes from 1500 BC-AC 1086
}

\author{
Anwen Cooper
}

This paper is about Bronze Age round barrows and the ways in which they became caught up in human practices over an extended time period. At one level it belongs to a flourishing body of work that examines the 're-use' or 'biography' of prehistoric monuments. Rather than treating the latter as a generic group, however, this study focuses on chronologies of one specific monument type - round barrows - over a 2600-year period from 1500 BC-AC 1086. By bringing together evidence and interpretations generated mainly within period specialisms, significant homogeneities are revealed in terms of how activities at prehistoric monuments have previously been understood. The possibilities for seeking out different interpretative ground are duly explored. Using a case study from the east of England and drawing on evidence and ideas from much more broadly, the approach taken places particular emphasis on examining relationships between round barrows and other aspects of landscape. The findings offer fresh insight into the temporality of activities undertaken at round barrows, question existing characterizations of past people's historical understandings, and explore the long-term coherence of 'round barrows' as a category.

\section{Introduction}

'In writing their cultural biography, once can construct many histories of urnfields'. (Fontijn 1996)

Round barrows are best known as funerary monuments of the Early Bronze Age (c. 2500-1500 BC), and have a western European distribution (Holst 2013, 103). Within Britain, it has increasingly been recognized that burial activities are just one subset of an array of practices undertaken at round barrows (see papers in Last 2007a). Much more widely it is recognized that many of them endured as landscape features long beyond their inception and early use. In this sense, round barrows can be understood as what Lucas $(2005,26)$ has termed resonant archaeological entities - they have persisted materially such that they have been part of people's lives over extremely 
long time periods. One outcome of this longevity is that round barrows are connective: they have provided common points of focus for communities at various different times in the past and they are of interest to researchers in many parts of a diverse discipline (Bradley 1987, 15).

The diversity of round barrows is a theme that has arisen persistently during their sustained research history. It has long been appreciated that round barrows are varied in their initial settings, construction sequences, material correlates, and overall forms (e.g. Colt Hoare in Cunnington 1975, 52; Garwood 2007). Many round barrows had lengthy histories, in some cases beginning in the Neolithic period (Bradley 2007, 78-84). Close relationships have also sometimes been observed between round barrows and Neolithic activity areas (e.g. Garwood 2007, 39-41; Last 2007b). Indeed given their long gestation periods, the diverse materials and building practices employed in their construction, and the assorted outcomes of this work (see Garwood 2007 for a useful summary of round barrow chronologies and forms) it is interesting to consider at what point in the past round barrows came to be understood as broadly similar phenomena. The rising intensity and extent of archaeological excavation over the last 30 years or so has also brought to the fore their assorted roles in landscapes over much longer time-periods. Following their initial construction and use, round barrows continued to attract burial practices, were built into settlements and fields, were reconfigured as monuments, and were sometimes also intentionally damaged or physically obliterated. Differences in their historical trajectories can be observed across wide areas and even within much smaller regions. Indeed the fact that round barrows are readily recognized and have seemingly well-understood connotations, yet continue to surprise us with their multiplicity, almost certainly contributes to their ongoing analytical allure.

Given this diversity, it is perhaps surprising that most studies that discuss longer-term practices at round barrows (and at prehistoric monuments more broadly) have returned to a fairly narrow range of interpretative themes. As noted above, various later activities have been recorded at round barrows. However these practices are almost invariably explained in similar ways (see also van Beek \& de Mulder 2014, 301-2). This observation becomes particularly clear once period-specific studies about later activity at prehistoric monuments are considered together (Table 1). 
Practices at prehistoric monuments are generally viewed as responses to their likely ancestral, supernatural and/or historical associations. More specifically it is argued that ancient structures were engaged with for three main purposes: as a means of creating local identities and senses of place, to legitimize land access, and in justifying the emergence of new social and political configurations. The role of social memory in such practices and the character of historical understandings involved are also often explored.

Most of these ideas were mooted very early on during research into this topic (e.g. Bradley 1987; Evans 1995; Lucy 1992; Williams 1998a,b; Semple 1998). Their persistence in subsequent archaeological narratives certainly testifies to the strength of these arguments. One major problem with this interpretative consensus, however, is that the explanations involved have arguably lost specificity even to researchers who use them. Van Beek and de Mulder's recent long-term account of later activities at prehistoric barrows in Belgium ends with the statement that it is impossible to decide whether these practices served to, for instance, "familiarize" ancient monuments, legitimize political authority, or strengthen territorial claims' (2014, 317; see also Crewe 2012, 14; Fokkens 2012, 568; Holtorf 1998, 34; Gerritsen 2007, 341; Semple 2009, 31). Perhaps surprisingly, however, this interpretative impasse has not previously been actively problematized.

Interestingly, the ideas used to justify (and thus ultimately to entrench further) this set of interpretations are drawn together from quite different analogical sources. Early medieval researchers take inspiration from late first millennium AC literary accounts of 'supernatural' barrow-dwellers - dragons, devils and so on (e.g. Semple 2013, Chapter 5). They also view the creation of written royal genealogies in the $8^{\text {th }}$ and $9^{\text {th }}$ centuries AC (often beginning with a pagan god and proceeding with legendary heroic figures) as evidence of a broader interest amongst early medieval elite groups in using created ancestries as a means of justifying political order (e.g. Crewe 2012, 29-30). Meanwhile researchers (mainly prehistorians) taking insight from ethnographic accounts of recent small-scale farming societies raise the important role played by supernatural beings (e.g. ancestors) in negotiating land claims and in justifying social order (e.g. Fokkens \& Arnoldussen 2008; Johnston 2001, 102; Williams 1997, 25). 


\begin{tabular}{|c|c|c|c|}
\hline Interpretation & Period & $\begin{array}{l}\text { Activity associated with } \\
\text { round barrow (where } \\
\text { specified) }\end{array}$ & References \\
\hline \multirow[t]{4}{*}{$\begin{array}{l}\text { Ancestral/supernatural/historical } \\
\text { associations of round barrows }\end{array}$} & $\begin{array}{l}\text { Later Bronze } \\
\text { Age }\end{array}$ & Land boundaries & $\begin{array}{l}\text { English 2013, } 13 \\
\text { Johnston 2001, } 102 \\
\text { Wickstead 2008, } 112\end{array}$ \\
\hline & Iron Age & $\begin{array}{l}\text { Land boundaries, burials, } \\
\text { settlements }\end{array}$ & $\begin{array}{l}\text { Artelius } 2013,37 \\
\text { Barrett 1999b, } 262 \\
\text { Gerritsen 2007, } 339 \\
\text { Giles 2012, 51 } \\
\text { Hingley } 1996\end{array}$ \\
\hline & Roman & Various & $\begin{array}{l}\text { Vermeulen \& Bourgeois } \\
2000,144-6 \\
\text { Roymans } 1995 \\
\text { Williams } 1998 \mathrm{a}, 71\end{array}$ \\
\hline & $\begin{array}{l}\text { Early } \\
\text { medieval }\end{array}$ & Various & $\begin{array}{l}\text { Crewe 2012, } 197 \\
\text { Semple 1998, } 121 \\
\text { Williams 1997, 7; } \\
\text { 1998b, 102; 2006, } 158\end{array}$ \\
\hline \multirow[t]{3}{*}{$\begin{array}{l}\text { Creating local identities/a sense of } \\
\text { place }\end{array}$} & Iron Age & Settlement & $\begin{array}{l}\text { Gerritsen 2007, } 340 \\
\text { Giles 2012, 68 } \\
\text { Hingley 1996, } 241\end{array}$ \\
\hline & Roman & & Williams 1998a, 77 \\
\hline & $\begin{array}{l}\text { Early } \\
\text { medieval }\end{array}$ & Settlement, burials & $\begin{array}{l}\text { Crewe 2012, } 145 \\
\text { Semple 2013, } 58 \\
\text { Williams 1997, 14; } \\
\text { 1998b, 103; 2006, } 158\end{array}$ \\
\hline \multirow[t]{4}{*}{ Legitimizing land claims } & Bronze Age & Settlement & $\begin{array}{l}\text { Fokkens \& Arnoldussen } \\
2008,8-9\end{array}$ \\
\hline & Iron Age & Land boundaries & $\begin{array}{l}\text { Artelius 2013, } 36 \\
\text { Giles 2012, } 51\end{array}$ \\
\hline & Roman & & Williams 1998a, 78 \\
\hline & $\begin{array}{l}\text { Early } \\
\text { medieval }\end{array}$ & Burials & $\begin{array}{l}\text { Lucy } 2000 \\
\text { Semple } 2013,26,37 \\
\text { Williams 1997, 24-5; } \\
2006,180\end{array}$ \\
\hline \multirow{3}{*}{$\begin{array}{l}\text { Justifying the emergence of new } \\
\text { social/political configurations }\end{array}$} & Iron Age & 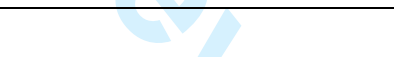 & Barrett 1999b, 263 \\
\hline & Roman & $\begin{array}{l}\text { Temple/shrine, burials, ritual } \\
\text { deposits }\end{array}$ & $\begin{array}{l}\text { Eckardt et al. 2009, } 85 \\
\text { Williams 1998a, } 78\end{array}$ \\
\hline & $\begin{array}{l}\text { Early } \\
\text { medieval }\end{array}$ & $\begin{array}{l}\text { Funerary and ritual activity, } \\
\text { settlement }\end{array}$ & $\begin{array}{l}\text { Blair } 1995 \\
\text { Bradley 1987, } 10 \\
\text { Crewe 2012, } 208 \\
\text { Lucy 1992, 96 } \\
\text { Semple 2013, 38, 60, } \\
\text { 195, 225 } \\
\text { Williams 1997, 25; } \\
\text { 1998b, } 103\end{array}$ \\
\hline \multirow[t]{3}{*}{$\begin{array}{l}\text { Role played by social memory, } \\
\text { character of past historical } \\
\text { understandings }\end{array}$} & Iron Age & Various & $\begin{array}{l}\text { Artelius 2013, } 37 \\
\text { Barrett 1999b, } 262 \\
\text { Giles 2012, 53 } \\
\text { Gosden \& Lock 1998, } 6 \\
\text { Hingley 1996, } 240\end{array}$ \\
\hline & $\begin{array}{l}\text { Later } \\
\text { prehistory }\end{array}$ & Various & Bradley 2002 \\
\hline & $\begin{array}{l}\text { Early } \\
\text { medieval }\end{array}$ & Various & $\begin{array}{l}\text { Bradley 1987, 4, } 10 \\
\text { Semple 2013, Chapter } 5 \\
\text { Williams 1998b, } 104\end{array}$ \\
\hline
\end{tabular}

Table 1: Examples of common interpretative themes raised in discussions of prehistoric, Roman and early medieval activity at round barrows 
My intention here is not to refute the relevance of these broad explanations. Detailed insights have, of course, been offered beyond these core topics and there is considerable subtlety to some of the arguments made. One difficulty with the repeated use of these explanations, however, is that while they offer a highly persuasive set of interpretative options at a general level, it is often very difficult to enhance them specifically using archaeological evidence. As van Beek and de Mulder (2014) came to appreciate it is rarely (if ever) possible, for instance, to argue convincingly that particular practices related to 'legitimizing land rights' rather than to 'creating local identities', or to consider in detail the specific kinds of 'local identity' that came to the fore during practices at round barrows. As Gosden and Lock noted 'the step from an acknowledgement that history mattered to being able to delineate how it mattered is a huge one' $(1998,3)$. Without access to such details, I would suggest that this set of understandings has lost their initial vibrancy and efficacy (see also Whitley's 2002 discussion of ancestral interpretations).

The aim here is to elicit slightly different interpretative emphases - to seek out 'other types of meaning' (Fontijn 1996, 85). It seems especially important to probe the discrepancy that has emerged between the disparate and lively character of round barrow histories and the somewhat conservative character of explanatory themes that have arisen in relation to them. It also seems vital to try actively to develop interpretations that employ more effectively the diverse qualities of round barrow histories. The following account outlines the findings of a detailed investigation into round barrow relationships from $1500 \mathrm{BC}-\mathrm{AC} 1086^{2}$. This work was undertaken as part of the European Research Council-funded English Landscape and Identities project based at the Institute of Archaeology, Oxford. The study necessarily takes methodological inspiration from and ties into existing studies of later activities at prehistoric monuments, both in Britain and beyond. The analysis also aims to tread new interpretative ground. Its geographical emphasis - on the east of England - and its extended timeframe set it apart from previous work. Additionally the investigative focus specifically on round barrows and on their relationships with other landscape elements opens up alternative interpretative possibilities. 


\section{Existing accounts of later activity at round barrows (and prehistoric monuments more broadly) in Britain}

This section provides a broad outline of existing accounts of later activity at prehistoric monuments, emphasizing pertinent aspects of these studies. Readers are referred to van Beek and de Mulder (2014) for a recent summary of such analyses at a European level. Semple (2013) covers in detail work in this area by early medievalists. Details of the time periods referred to in this section and throughout the remaining text, are outlined in Table 2.

\begin{tabular}{|l|l|l|l|}
\hline Broad period & Dates & Sub-period & Dates \\
\hline \multirow{3}{*}{ Bronze Age } & $2300-800 \mathrm{BC}$ & Middle Bronze Age & $1500-1150 \mathrm{BC}$ \\
\cline { 3 - 4 } & & Late Bronze Age & $1150-800 \mathrm{BC}$ \\
\cline { 3 - 4 } & & Later Bronze Age & $1500-800 \mathrm{BC}$ \\
\hline \multirow{3}{*}{ Iron Age } & & Early Iron Age & $800-400 \mathrm{BC}$ \\
\cline { 3 - 4 } & & Middle Iron Age & $400-100$ BC \\
\cline { 3 - 4 } & & Late Iron Age & 100 BC-AC 42 \\
\hline Later prehistory & 1500 BC-AC 42 & - & - \\
\hline Roman & AC 43-410 & Early Roman & AC 43-125 \\
\cline { 3 - 4 } & & Middle Roman & AC 125-275 \\
\cline { 3 - 4 } & & Late Roman & AC 275-410 \\
\hline Early medieval & AC 410-1065 & Early early medieval / & AC 410-650 \\
& & Early Anglo-Saxon & \\
\cline { 3 - 4 } & & Middle early medieval & AC 650-850 \\
\cline { 3 - 4 } & & Late early medieval & AC 850-1065 \\
\hline
\end{tabular}

Table 2: Traditional periods and sub-periods referred to in the text

Later Bronze Age activity

Discussions about later Bronze Age activity at prehistoric monuments in Britain are remarkably rare. Studies that have contributed to understandings of this topic are summarized elsewhere (Cooper 2016). It is sufficient to note here that the previous lack of interest in this theme probably relates to a strong (and important) desire by British researchers to explain why the elaborate ceremonial practices undertaken at monuments during the Neolithic and Early Bronze Age lost their place in people's lives with the emergence of a new suite of architectures and depositional practices in the mid second millennium BC (visible settlement architecture, extensive field systems and metalwork deposits) (Barrett 1994, 5; Bradley 2007 Chapter 4). Having said this, it has been recognized for some time that fields frequently referenced, 
respected, avoided, or slighted existing funerary monuments (e.g. Bradley 1993, 2002, 2007; English 2013; Yates 2007); and that 'long-lasting' structures (stone-built round houses, cairns, round barrows etc.) were almost certainly a significant feature of later Bronze Age landscapes (e.g. Johnston 2005, Wickstead 2008). Recent studies of later Bronze Age cremation practices at a regional and national level also demonstrate that round barrows were a particular focus for Middle Bronze Age cremation burials in certain regions (Robinson 2007), and that in other areas of Britain such practices took place well into the first millennium BC (Caswell 2013).

\section{Iron Age activity}

No systematic survey of Iron Age activity at prehistoric monuments has been undertaken in the UK. However Iron Age researchers have played a prominent role more generally in raising awareness of the multi-temporal qualities of landscape engendering a sense that at all times peoples' lives comprise accretions of matter with different origins and of varying durability (Olivier 1999). They have also made significant contributions to discussions about prehistoric understandings of the past and the kinds of memories and histories that were produced during encounters with older architectures and materials (e.g. Barrett 1990, 1999a, 1999b; Gosden \& Lock 1998). One interesting outcome of these debates is the contention that during the Iron Age, for the first time, existing structures such as round barrows came to be understood as belonging to a time that was distanced or detached from living memory (Barrett 1999b, 262; Gosden \& Lock 1998, 11). Barrett illustrates this point specifically through a discussion of what he suggests is an absence of Iron Age burials at round barrows (1999b, 261).

While early discussions about Iron Age activity at prehistoric monuments were conducted at a rather abstract level, recent accounts are more empirically grounded (e.g. Giles 2012, Chadwick 2016). Giles (2012) examines relationships between Iron Age evidence and round barrows in East Yorkshire. Round barrows were sometimes skirted by or incorporated into extensive Early Iron Age land boundary systems but were also sometimes damaged or levelled during their construction. Very occasionally cremation burials and other material fragments (e.g. pottery sherds) 
were also interred in round barrows at this time. During the Middle Iron Age, several square barrow cemeteries in East Yorkshire were located with clear reference to prehistoric monuments (Giles 2012, 68) even though overall, the distribution of round barrow and square barrow cemeteries in this region was quite different (e.g. Stoertz 1997, 36-8). Giles also raises the important point that existing architectures and materials would have played an active role in processes of identity making.

Encounters with the earthworks themselves and with the pottery, flint and human remains within them would have prompted the creation of new histories that situated these relics in an Iron Age present (2012, 51). More broadly, Hingley (2009) suggests that the occurrence of Bronze Age artefacts in Iron Age hoards implies a wider interest in 'ancient' materials during this period.

\section{Roman activity}

Studies of Roman activity at prehistoric monuments are also scarce - they include one broad synthesis (Williams 1998a), and several useful supporting accounts (Aitcheson 1998; Dark 1993; Eckardt et al. 2009; Hutton 2011). It is now widely recognized that a specific set of practices was undertaken at prehistoric monuments in this period in England. Religious architectures (shrines and temples) were built on or close to these features, the dead were buried in them, and they were associated with unusual material deposits (Williams 1998a, 74-5). Williams argues at a broad level that Roman barrows tend to be located close to Bronze Age antecedents (1998a, 75). More specifically, and conversely, Eckardt et al. suggest that Bronze Age and Roman funerary monuments in southern Cambridgeshire occupy very different landscape positions $(2009,68)$.

Prehistoric monuments provided a focus for activities throughout the Roman period and across England and Wales. A shift from Early Roman cremations to Late Roman inhumations at prehistoric monuments is noted (Williams 1998a, 72). Material deposits are also recorded more frequently in such contexts in the Late Roman period (e.g. Williams 1998a, 72). Williams (1998a) highlights the 'ritual' emphasis of activities undertaken at prehistoric monuments, presenting them as part of a much broader suite of Romano-British religious expressions. Meanwhile Hutton stresses 
the often 'everyday' or 'personal' character of Roman material deposited in a range of contexts including prehistoric monuments (mostly Neolithic long mounds and monument complexes) $(2009,14)$. Regarding round barrows in particular, Hutton $(2009,12)$ suggests that prominent (i.e. substantial) mounds were chosen preferentially for depositional acts. Williams also mentions that round barrows often operated as raised platforms for the siting of temples (1998a, 72).

\section{Early medieval activity}

Researchers have for a long time recognized and discussed the occurrence of early medieval burials at Bronze Age round barrows (e.g. Meaney 1964; Shepherd 1979). However detailed investigation of early medieval activity at prehistoric monuments (and to a lesser extent at enduring Roman sites) has been particularly intense over the last 25-30 years. Bradley (1987), Lucy (1992, 1998, 2000), Semple (e.g. 1998, 2004, 2009, 2013) and Williams (e.g. 1997, 1998, 2003, 2006) have played leading roles in this movement. Blair (1995, 2005), Brookes (e.g. 2007), Chester-Kadwell (2009), Crewe (2012), Eckardt and Williams (2003), Petts (e.g. 2002) and Reynolds (e.g. 1999, 2002, 2009) have made further major contributions. Despite the wealth of research into this topic, recent accounts highlight considerable scope for probing regional particularities further (e.g. Semple 2009, 35; Williams 2006, 185).

It is important to stress that round barrows were one of a suite of 'potent' landscape features - including prehistoric monuments, Roman remains, and various topographic features (springs, rock fissures, meres etc.) - that were a focus for early medieval activity (Semple 2013, 85-6). Even so, round barrows were clearly of particular interest during this period. Williams' $(1997,4)$ suggestion that the majority of early medieval burials at prehistoric and Roman sites were located at round barrows has generally been upheld (e.g. Crewe 2012, 115, Semple 2013, 107) ${ }^{3}$.

A broad range of activities was undertaken at prehistoric monuments during the early medieval period. However clear temporal trends and marked regional differences particularly in burial practices - have been identified (Table 3). It is widely accepted that a major change in the character of practices at prehistoric monuments took place 
from the late seventh century AC onwards - the period during which Christianity was widely adopted and kingdoms gradually took shape. Semple (2013) also suggests that attitudes towards prehistoric monuments shifted significantly at around this time. In the fifth to seventh centuries AC people viewed themselves as having personal historical ties to prehistoric monuments. From the eighth century AC onwards, however, they were rendered as belonging to a distant heathen past (Semple 2013, 207).

\begin{tabular}{|c|c|c|c|}
\hline Period & Activity & Further details & $\begin{array}{l}\text { Key } \\
\text { references }\end{array}$ \\
\hline \multirow[t]{5}{*}{$\begin{array}{l}\text { Fifth to late } \\
\text { seventh } \\
\text { centuries AC }\end{array}$} & Funerary & $\begin{array}{l}\text { A fifth to sixth-century AC emphasis on collective burials } \\
\text { is noted. During this time there is little sense that grave } \\
\text { goods were used to differentiate between people. Burials } \\
\text { at prehistoric monuments became more popular overall in } \\
\text { the seventh century AC. In some areas single richly- } \\
\text { furnished burials were made at this time. New round } \\
\text { barrows were also created for funerary purposes. }\end{array}$ & $\begin{array}{l}\text { Lucy } 1998 \\
\text { Williams } 1998 \\
\text { Semple } 2013\end{array}$ \\
\hline & Settlement & $\begin{array}{l}\text { In the fifth to sixth centuries an association developed } \\
\text { between sunken-featured buildings and prehistoric } \\
\text { monuments. From the seventh century onwards } \\
\text { monuments were integrated more formally into settlement } \\
\text { contexts. }\end{array}$ & Crewe 2012 \\
\hline & $\begin{array}{l}\text { Shrines and } \\
\text { 'ritual } \\
\text { deposits' }\end{array}$ & $\begin{array}{l}\text { Iron weapons, jewelry, dress accessories and coins (or } \\
\text { Roman and early medieval origin) were deposited, } \\
\text { particularly in the sixth and seventh centuries. }\end{array}$ & $\begin{array}{l}\text { Blair } 1995 \\
\text { Semple } 2013\end{array}$ \\
\hline & Battles & 'Ritualized encounters' between small groups. & Semple 2013 \\
\hline & Markers & Trees, crosses, stone pillars, posts. & Semple 2013 \\
\hline \multirow[t]{5}{*}{$\begin{array}{l}\text { Eighth to } \\
\text { eleventh } \\
\text { centuries AC }\end{array}$} & Funerary & $\begin{array}{l}\text { Round barrows in particular became a focus for public } \\
\text { executions and burials. From the tenth century AC } \\
\text { onwards few interments were made at prehistoric } \\
\text { monuments. }\end{array}$ & $\begin{array}{l}\text { Reynolds } 2009 \\
\text { Semple } 2013\end{array}$ \\
\hline & Settlement & $\begin{array}{l}\text { 'Planned' settlements and 'palace complexes' in } \\
\text { particular. Round barrows were sometimes carefully built } \\
\text { into the layout of these settlements. }\end{array}$ & Crewe 2012 \\
\hline & Churches & & Blair 2005 \\
\hline & $\begin{array}{l}\text { Public } \\
\text { gatherings }\end{array}$ & Including major council meetings. & $\begin{array}{l}\text { Baker et al. } \\
\text { forthcoming } \\
\text { Semple } 2013 \\
\end{array}$ \\
\hline & $\begin{array}{l}\text { Land } \\
\text { boundaries }\end{array}$ & & $\begin{array}{l}\text { Brookes, } 2007 \\
\text { Petts } 2002 \\
\text { Reynolds } 2002 \\
\end{array}$ \\
\hline
\end{tabular}

Table 3: Summary of chronological changes in early medieval activities undertaken at prehistoric monuments

Late early medieval written sources - poetry, prose, placenames, charter-bounds and imagery offer intriguing insight into how prehistoric monuments were understood at this time (Fig. 1). Although these sources were created by a literary few, it is certainly possible that they crystalize ideas that were held much more widely in society and had developed over considerable time periods before they were written 
down. Placename and charter-bound evidence expresses a clear interest in describing prehistoric monuments in terms of their form, colour, fabric, age and condition (e.g. whether they had been dug into), and their associations with people, animals and other landscape elements (Semple 2013, 160-3). Round barrows were often depicted in poetry and prose as the haunts of ambivalent beings (dragons, devils, elves, ghosts, monsters, phantoms, witches, etc.) or as settings for the exile of tormented human characters - criminals, a grieving woman, and troubled saints (Semple 2013, 146-55).

Two of the early medieval studies mentioned above and one main early medieval written source are also directly relevant to the following analysis. Recent studies by Crewe (2012) and Chester-Kadwell (2009) cover aspects of the Early Anglo-Saxon evidence at round barrows from the case study area examined here in the east of England. One eighth-century AC narrative that is employed heavily in discussions of early medieval activity at prehistoric monuments - Felix's 'Life of St Guthlac' (e.g. Williams 2006, 205; Semple 2013, 151) - provides a vivid portrayal of the east Anglian fenland, located at the centre of the case study area.

Overall, existing understandings of activities undertaken at round barrows in Britain during the time frame under consideration here are variable. At one extreme - for the early medieval period - practices of this kind have received detailed scrutiny. At the other - for the later Bronze Age - this topic has barely been touched on. Prehistoric monuments have typically been dealt with as a generic group. Meanwhile British researchers' tendency to work within traditional period boundaries has constrained the creation of diachronic understandings of such practices. It has been suggested that strands of continuity exist in the makeup of 'ritual activity' at prehistoric monuments across the Late Iron Age/Early Roman (e.g. Eckardt et al. 2009, 85; Hutton 2011, 15) and the Late Roman/early medieval period transitions (Blair 1995; Williams 1998a, 77). However no concerted attempt has been made to chart systematically the character of practices undertaken at prehistoric monuments over longer durations - timespans that extend beyond period boundaries and the centuries immediately to either side of them. This study aims explicitly to address this issue. 


\section{Method}

The approach developed here draws on key methodological insights from existing studies of later activities at prehistoric monuments both in Britain and on the near Continent. One important aspect of the method used here is that it places one particular prehistoric monument type - round barrows - at the centre of a long-term analysis. Prior to this study, long-term perspectives of prehistoric monuments have been produced only on the near Continent (e.g. Holtorf 1998; van Beek \& de Mulder 2014; Roymans 1995; Roymans \& Gerritsen 2002). One advantage of examining round barrow histories over an extended time period is that it enables consideration of the trajectory of activities conducted in these contexts across period boundaries. It also makes it possible to ask whether 'round barrows' (as opposed to prehistoric monuments more broadly) played a particular role in landscape histories and, indeed, whether the identity of these features was consistent throughout the period under consideration. Another important element of the method used here is its inclusivity. Rather than seeking out certain kinds of activities that were undertaken at round barrows (e.g. burials), all later evidence recorded at these features is seen as being potentially relevant. One strength of this approach is that it balances out the selective tendencies of existing studies of later activity at prehistoric monuments (e.g. Williams 1998b; Crewe 2012). Another is that it facilitates consideration of the interrelationship between different landscape elements rather than channelling attention towards one or other particular kind of practice.

The decision to focus here on evidence from one specific case study area responds to recent calls within Britain to undertake further work at a detailed regional level (see above). The emphasis placed upon characterizing relationships between later activities and round barrows responds broadly to a movement within prehistoric landscape studies which recognizes that archaeological entities (social identities, monuments, artefact types etc.) are produced through their associations with other phenomena rather than being static or self-evident (e.g. Giles 2012, 33-8). More specifically it develops a method used productively within studies of later activity at prehistoric monuments in general (e.g. Holtorf 1998; Semple 2009; Crewe 2012). For instance Semple's (2009) distinction between 'intrusive' and 'associative' burials - 
those which cut into and those which clustered close to prehistoric monuments allowed her to elicit clear regional differences in the funerary practices undertaken in such contexts (2009, 32-3).

The east of England case study area was chosen in part because this region is covered only very partially in existing analyses of later activity at prehistoric monuments. This area has also benefited from a wealth of recent, high-quality and extensive developer-funded excavations; this makes it easier to investigate associations between round barrows and later practices beyond straightforward spatial coincidence. The study area comprises 4650 square $\mathrm{km}$ spanning the limestone and boulder clay landscapes of Northamptonshire to the mixed heath of the Suffolk and Norfolk Breckland (Fig. 2). Two major rivers - the Nene and the Great Ouse - traverse it from north to south. Throughout the time period considered here the central part of the study area comprised a shifting coastal wetland - the East Anglian fenland - punctuated by islands of higher ground (Waller 1994).

The core analytical dataset comprises evidence for the period 1500 BC-AC 1086 relating to 87 'excavated' round barrows that can be grouped into 40 'sites' (single barrows or barrow groups $)^{4}$. The 87 excavated round barrows were logged within 53 digital records drawn from local Historic Environment Records (HERs), Historic England's (HE's) National Record for the Historic Environment (NRHE) and Excavation Index (EI), Online Access to the Index of Archaeological Investigations (OASIS), and the British and Irish Archaeological Bibliography (BIAB) ${ }^{5}$. These 53 records formed a starting point for the analysis and were selected from a total pool of 173 digital records relating to excavated round barrows within the study area. Priority was given to examining excavated sites with easily accessible reports ${ }^{6}$. Beyond this, the aim was to achieve broad spatial coverage across the study area and to focus on round barrows that had been investigated during recent (often extensive and highquality) fieldwork. Key sites mentioned in the text and their associated bibliographic references are listed in Table 4 and highlighted in the relevant figures. In the following analysis, unless otherwise stated, the findings under discussion relate to this core dataset. 
For each excavated round barrow site, the relevant reports were examined in detail. All activity relating to the period $1500 \mathrm{BC}-\mathrm{AC} 1086$ that was located within $50 \mathrm{~m}$ of an existing round barrow, and round barrows that potentially originated in this period, were logged in a database. Key traits that were recorded in the round barrow relationships database are summarized in Appendix 2. In order to contextualize the main findings, digital records for all 173 excavated round barrow sites within the study area were enhanced within the EngLaID project database (see Cooper \& Green 2016 for a summary of the database makeup). This involved creating separate 'monument types' for all later activities that were mentioned in the 'site descriptions' of digital records but were not otherwise represented either as analysable 'monument types' or in separate records.

\begin{tabular}{|l|l|l|l|}
\hline Site name & County & Landscape area & Reference(s) \\
\hline Hermitage Farm, Haddenham & Cambridgeshire & Lower Great Ouse & Hall et al. 1987 \\
\hline Snow's Farm, Haddenham & Cambridgeshire & Lower Great Ouse & Evans \& Hodder 2006 \\
\hline Over Low Grounds & Cambridgeshire & Lower Great Ouse & Evans et al. forthcoming \\
\hline Site IV, Colne & Cambridgeshire & Lower Great Ouse & Evans et al. 2013 \\
\hline Rhee Lakeside (South) & Cambridgeshire & Lower Great Ouse & Evans et al. 2013 \\
\hline King's Dyke West & Cambridgeshire & & Gibson \& Knight 2002 \\
\hline Tallington & Lincolnshire & & $\begin{array}{l}\text { Fennell 1961; Simpson } \\
\text { Crimplesham }\end{array}$ \\
\hline Oxborough & Norfolk & & Bates 2008 \\
\hline South Acre & Norfolk & & Penn 1998 \\
\hline Crow Hall Park & Norfolk & & Wymer, J. 1996 \\
\hline Irthlingborough & Norfolk & & Percival \& Trimble 2008 \\
\hline Stanwick & Northamptonshire & Raunds & Harding \& Healy 2007 \\
\hline West Cotton & Northamptonshire & Raunds & Harding \& Healy 2007 \\
\hline Elton Estate & Northamptonshire & Raunds & $\begin{array}{l}\text { Harding \& Healy 2007; } \\
\text { Chapman 2011 }\end{array}$ \\
\hline Pode Hole Farm & Northamptonshire & & Barlow 2008 \\
\hline The Sandpits, Lakenheath & Peterborough & Thorney & $\begin{array}{l}\text { Daniel 2009; Ellis et al. } \\
2001\end{array}$ \\
\hline Liberty Village, Lakenheath & Suffolk & Eriswell & Craven 2004 \\
\hline Hospital Car Park, Lakenheath & Suffolk & Eriswell & Craven 2012 \\
\hline
\end{tabular}

Table 4: Key excavated sites mentioned in the text

Round barrow relationships in the east of England, $1500 \mathrm{BC}-\mathrm{AC} 1086$ 


\section{Broad patterning}

To begin, it is worth noting that round barrows in the east of England had a strong and fairly consistent set of associations prior to the period under consideration here. Over 80 per cent of records relating to excavated round barrows were located within $50 \mathrm{~m}$ of Neolithic activity recorded in the NRHE - areas that may have already been cleared already of mature trees and scrub (see also Last 2007b). A clear clustering of round barrows is evident along major valley systems and along the fen edge, particularly in the western and central parts of the study area (Fig. 2). Several of these round barrows were also located close to natural mounds and substantial trees (e.g. Healy \& Harding 2007, 60-5). Beyond this, their landscape associations (soil types, geologies, elevation etc.) were highly variable ${ }^{7}$.

Based on evidence from all 173 records relating to excavated round barrows, landscapes that included round barrows were common locations for activity throughout the study period in the east of England (Fig. 3a). Over this period, however, the number of round barrow sites that became a focus for activity waned (Fig. 3b). Considering the broad character of activities at the sites examined in detail, practices undertaken at round barrows in the later Bronze Age were both more focused in their makeup (Fig. 4a), and engaged more intently with the monuments it was almost always clear that the activity concerned was intentionally (rather than incidentally) associated with a round barrow ${ }^{8}$. During the Iron Age in particular, both the purpose and character of practices located at round barrows was open-ended. Levelling or remodelling round barrows was a significant element of the diverse activities undertaken at round barrows in both the Iron Age and Roman periods (Fig. 4b). The overall incidence of early medieval activity at round barrows is low. However, where it did occur, it was often purposeful in character and consistent in its makeup in contrast to the situation for the Iron Age and Roman periods.

A very general shift in emphasis from living in the vicinity of round barrows in the later Bronze Age (locating settlements, settlements and a range of other activities close to them), to engaging with them more sporadically and remotely (in the sense that the focus of most activities was elsewhere) can also be suggested. This point is accentuated if the spatial distances between records of excavated round barrows 
and records of all other modes of later activity logged in the EngLalD database are plotted (Fig. 5) . $^{9}$ Based on accessible measures (the maximum diameter of single barrows, and the number of barrows within discrete groups), and, notably, contrary to previous assertions (e.g. Hutton 2011, 12; Semple 2013; Williams 2006, 187), there is little evidence to suggest that 'prominent' round barrow sites were chosen preferentially as settings for later activity. Additionally - and this time in accord with broader patterning in some areas (e.g. Stoertz 1997; Giles 2012, 68; see however Bradley 2002, 130-40) - only very rarely were Bronze Age round barrows an active focus for the construction of later barrows (Iron Age square barrows, early medieval barrows). Moreover only in the early medieval period was there any sense that 'new' barrows were understood and used in similar ways to Bronze Age examples (see Appendix 4 for a list of Iron Age, Roman and early medieval barrows within the study area).

\section{Specific patterning}

A detailed account of later Bronze Age activity at round barrows examined for this study is given elsewhere (Cooper 2016), although a brief summary is presented below. The main focus here is therefore on elements of Iron Age, Roman and early medieval activity at excavated round barrow sites that contribute specifically to existing understandings of such practices.

\section{Later Bronze Age activity}

The high incidence and relatively coherent character of later Bronze Age activity at round barrows made it possible to develop a nuanced understanding of their role more broadly in landscapes in this period. Round barrows were clearly an important part of later Bronze Age lives in various different ways.

Evidence for this period provides tantalizing insight into the different scales at which 'communities of practice' operated (Cohen 1985; see also Gerritsen 2003). The character of funerary practices at round barrows cohered at a valley-wide scale - six 
of the seven later Bronze Age cremation cemeteries at round barrows examined in detail (including all of those comprising 10 or more burials) were located along the Great Ouse Valley (Fig. 6) ${ }^{10}$. There were also commonalities in the choreography of these cemeteries - the manner in which cremation pits intercut and in which cremations clustered within the overall burial group. Understandings about how to deal with round barrows in constructing field systems were apparently devised more locally. A specific set of grammars is recognizable in terms of how Middle Bronze Age land boundaries intersect directly with round barrows. In some landscapes they stop immediately short of or alongside round barrows, in others they cut slightly into ring ditches, elsewhere they slice directly across them. Interestingly such relationships were enacted more consistently within extensively excavated landscapes than they were between them (Fig. 7).

Relationships between later Bronze Age settlements and round barrows are less clear-cut. Occupation debris of that date is found fairly often in features relating to round barrows (in pits or in partly infilled ring ditches). However more substantial settlement remains tend to be set slightly apart from them. The occurrence of substantial in-situ flint-working deposits at several round barrows highlights that as well as being engaged with during more conspicuous burial and architectural (monument and field-building) practices, these features were also settings for relatively fleeting ventures (Fig. 8).

Iron Age activity

Iron Age engagements with round barrows in the study area are often subtle - they are mainly represented by material traces and isolated pits. Fragments of Iron Age pottery and occasionally other items (e.g. an Icenian coin at Oxborough) occur frequently within ring ditches, mound material and in the ploughsoils overlying of round barrows (Fig. 9). Such occurrences are easily explained away as representing stray losses or debris from nearby settlement or agricultural activity (e.g. Craven 2012). Contextual details, however, suggest that care should be taken in dismissing these fragments. Complete Iron Age pots were recovered from two round barrows. The vessel from The Sandpits is associated with further broken pots and a Middle 
Iron Age cremation. That from Snow's Farm is associated with a possible Late Iron Age shrine. Three round barrows at Irthlingborough produced (probably Late) Iron Age pottery sherds, even though they are located c. $1 \mathrm{~km}$ from the nearest known settlement of this date. Pits containing Iron Age occupation debris were identified at six round barrow sites. In three cases (e.g. at Tallington) the pits were probably associated with wider settlement activity. The remaining examples, however, were seemingly isolated - potentially representing ephemeral 'camps' (e.g. Evans et al. forthcoming; Hall et al. 1987, 175).

Two trackways potentially of Iron Age origin were directly associated with round barrow sites. One (at Elton Estate) was diverted to avoid a round barrow; the other (at Liberty Village) runs parallel to a pair of round barrows in its course from the chalk upland to the fen edge. At Tallington, an Early Iron Age (700-400 BC) pit alignment traverses directly a barrow cemetery that was also a focus for further Iron Age activity (Fennell 1961; Simpson 1976) ${ }^{11}$. These examples highlight the broad structuring role that round barrow sites sometimes played in Iron Age landscapes.

More substantial Iron Age settlement evidence was located at eight round barrow sites. In these contexts, it appears, people dealt variously with round barrows. In some cases (e.g. the Early Iron Age settlement at King's Dyke West and the MidLate Iron Age settlement at Rhee Lakeside (South)) there is little evidence to suggest that round barrows were engaged with actively. Elsewhere (e.g. at Site IV, Colne), settlement features - mainly enclosure ditches - were cut directly through round barrows, presumably levelling their remains. In these contexts, it is feasible (but unlikely) that the round barrows involved were no longer visible in the Iron Age. In each case, however, it is possible to argue - based on the choreography of other settlement boundaries, the central positioning of transgressive ditches, and/or the character of other features and deposits nearby - that the destructive gesture was intended. At Site IV, Colne, for example, Early Iron Age boundaries curve as if to accommodate a ring ditch and a possible square barrow is positioned immediately to the west of it. Although the ring ditch was effectively eclipsed in the Middle Iron Age when a more substantial settlement developed, human remains of this date - a cremation, an inhumation and a human skull fragment - are still concentrated in the same area of the site (the skull fragment was recovered from the in-filled ring ditch 
itself) (see Evans et al. 2013, 164-74 for an alternative interpretation of this relationship). It is certainly possible that collective understandings of round barrows were sometimes contested in settlement contexts at this time.

\section{Roman activity}

The range of activities found at round barrow sites in the Roman period was broadly similar to that for the Iron Age. However Roman practices were arguably more formalized and more assertive in character. In line with general surveys (e.g. Williams 1998a), an emphasis on 'ritual' practices is evident - round barrows were settings for formal burials and other unusual deposits and for the construction of temples/shrines. Detailed analysis adds significant nuance to previous observations, however (Fig. 10).

Potential Roman burials were encountered at only four round barrow sites in the study area. In two of these cases the evidence is ambiguous. Only the fourth century AC burials identified in round barrows at Stanwick - an inhumation within a recut cshaped ring ditch, and a child's skull deposited in another round barrow operating primarily by this time as a temple (see below) - conform closely to funerary practices recorded at round barrows more broadly (e.g. Williams 1998a).

Roman shrines or temples were located on or close to three round barrow sites (at Snow's Farm, Stanwick and King's Dyke West). These features were dissimilar in their construction, in the nature of deposits made, in their origins and intensity of use, and in how they related both to existing round barrows and to other Roman activity nearby. The notion that round barrows offered an appropriate context for building ritual architectures was clearly widespread at this time. However there was little apparent consensus regarding the specific practices involved. One interesting feature of the temple at Stanwick was that over its many phases of construction - potentially involving the creation of water features and stone walkways - the round barrow upon which it was built was remodelled substantially. This raises the interesting question of whether its identity as a 'round barrow' was actually evident or in any way significant 
during its later use. It is certainly possible that its initial associations were ultimately lost - this 'round barrow' essentially became a 'temple'.

Small assemblages of Roman pottery sherds and other fragmentary items were found at 10 round barrow sites (at 12 separate round barrows). This material provides an important context for the ritual deposits made at round barrows associated with formal shrines and temples. It includes 'everyday' fragments such as pottery, building materials and animal bones, and also more 'showy' items - toilet sets, jewelry, weapons. Such fragments may sometimes have entered round barrow contexts incidentally through manuring or ploughing. However it is worth emphasizing that pots were one of a range of items that were deposited formally both in round barrows and at other selected locations during this period (e.g. at the edge of a palaeochannel at West Cotton, Chapman 2010, 28). Additionally none of the round barrows concerned were located within or immediately adjacent to substantial Roman settlements.

Occasionally Roman items were clearly deposited at round barrows as part of carefully choreographed ceremonies. Two deposits at round barrows at Irthlingborough stand out for their martial and somewhat performative qualities. An Early Roman lance, two sling-shots and over $6 \mathrm{~kg}$ of pottery sherds were deposited immediately outside one ring ditch. Another ring ditch produced two halves of a first or second-century AC sword placed directly above one another, and over $1 \mathrm{~kg}$ of pottery fragments. Contrary to previous observations (e.g. Williams 1998a, 72), there is no evidence to suggest that formal deposits were made at round barrows primarily in the Late Roman period. Additionally, and again in contrast to patterning more broadly (Williams 1998a, Appendix 1), only one collection of coins was encountered at round barrows in the study area (beyond the formal round barrow-shrine at Stanwick, Parry \& Blinkhorn 2006, 170).

The assemblage of Roman coins from a ring ditch at Liberty Village, does, however, raise a broader question regarding the provenance of such deposits. The coins were of various dates, and Roman (and Iron Age) pottery and an arrangement of pig skulls/forelimbs were found close proximity. This deposit may well represent Roman activity. However it is important to note that collections of Roman coins were also 
deposited at round barrows during the early medieval period (e.g. Crewe 2012, 143), and that seven late seventh/early eighth-century AC graves were also cut into this round barrow. Whatever the date of this deposit, it does seem interesting more broadly that engagements with round barrows beyond their initial period of use not only potentially resulted in encounters with items of different temporal origins people in the past also curated collections of items of multiple origins and deposited them in these contexts.

Roman settlements were rarely located close to round barrows in the study area. However fields, trackways and roads did occasionally coincide with them. During the construction of these linear features, round barrows were sometimes attended to and were otherwise erased. In one extensively excavated landscape - at Hospital Car Park - a Roman field system frames one round barrow and turns and stops, seemingly respectfully at another. However in four of the five remaining cases where trackways, roads or field boundaries overlap spatially with round barrows they run straight through the centre of the monument. The evidence from King's Dyke West is particularly interesting in this respect. Here, the Early Roman Fen Causeway was built directly over the remains of one small ring ditch within a monument complex comprising a henge and two round barrows. Another (larger) round barrow was built carefully into its course. The placement of two Early Roman burials in roadside ditches adjacent to the preserved round barrow and the construction of two small shrines just beyond, suggest that the incorporation of the round barrow formed part of a broader suite of ritual practices.

\section{Early medieval activity}

Early medieval activity at round barrows in the study area is in some ways more interesting for its relative paucity than it is for its positive constitution. In terms of their range and temporal patterning, the practices involved conform broadly to the findings of existing studies (Fig. 11).

Cemeteries relating to all phases of the early medieval period were located at round barrows. However, three of the six examples date specifically to fifth/sixth centuries 
AC, and cemeteries of this period were more extensive, and more elaborate in their makeup - the graves were sometimes very richly furnished (e.g. at Hospital Car Park, Caruth \& Anderson 2005; Caruth forthcoming). There is little evidence that burial activity at round barrows escalated or became more exclusive in the seventh and eighth centuries (see also Williams 1997, 22). In all cases, graves were arranged carefully relative to the monument - typically cutting directly into ring ditches or barrow mounds (Fig. 12). The well-known and extensive cemetery at South Acre (comprising 126 graves of which many are thought to be execution victims) is the only example that includes burials dating to the ninth and tenth centuries AC (skeletal material from two graves at this site produced mixed radiocarbon dates of 14081825 cal. BP (HAR-10239) and 933-1255 cal. BP (HAR-10238), Wymer 1996, 88-9). Significantly, evidence from the Raunds landscape, reinforces Chester-Kadwell's observation that early Anglo-Saxon communities did not feel compelled in any way to bury their dead at existing monuments even when the latter were both conspicuous and near at hand $(2009,27)$. Despite the unusual wealth of prehistoric monuments at Raunds, and the range of activities undertaken at them in all periods under consideration (an early medieval sunken-featured building was cut into the top of the long barrow at West Cotton), no early medieval burials were identified at round barrows in this landscape or at prehistoric monuments more broadly.

No architectural evidence for early medieval shrines was identified at round barrow sites in the study area. However infrequent occurrences of early medieval pottery and metalwork in ring ditch fills - an iron knife at Tallington, a late early medieval strap end at Crimplesham - suggest that round barrows did operated occasionally as formal depositional contexts. The contents of one pit adjacent to a ring ditch at Crow Hall Park are certainly interesting - they include 'placed' cattle skulls, and bones from a white-tailed eagle and an Ichthyosaur. Since this deposit forms part of a wider spread of domestic activity, however, it is difficult to tell whether it was made in response to the round barrow or alternatively constitutes an aspect of wider settlement practice (e.g. Crewe 2012, 206; Hamerow 2006).

Early medieval settlements overlap spatially with round barrows in six contexts. Only in two cases, however, does it appear that the round barrow was engaged with physically. Boundary ditches were positioned carefully relative to the round barrow 
within the eighth century AC settlement at Crow Hall Park. Given that there is wider evidence for such associations (e.g. Semple 2013, 211-2), it is certainly possible that the presence of a remarkable prehistoric monument complex was a factor in the siting of the high-status tenth century AC planned settlement at West Cotton. More specifically, the boundaries radiating from the main building-complex at this site frame neatly one of the round barrows (Chapman 2010, 62).

It is also worth commenting further on the overall scarcity of early medieval activity at round barrows, particularly in the central part of the study area - a finding both of this analysis, and of Crewe's (2012) wider survey of settlement activity at prehistoric monuments across central England, which produced a notably low figure for Cambridgeshire. Crewe suggests that this pattern could relate to a heightened interest in re-colonizing Roman (rather than prehistoric) remains in this region (2012, 118) - a possibility that needs further testing. I would add the (perhaps obvious) point that any examination of archaeological patterning in this geographical zone must take account of the morphing fenland at its core. Once round barrows are mapped against a reconstruction of the fen edge at C. AC 700, it is clear that most (c. 80 per cent) of those within the broad fenland area would have been inundated by this time (Fig. 13). This amounts to almost one third of all excavated round barrow sites in the entire study area. Those that remained would have been elevated above the fen on gravel islands or on peninsulas extending into it from the mainland. Hall and Coles also note that further areas of land would have been 'drowned' after this time $(1994,123)$. Of course this process would have played an important role in shaping early medieval people's engagement with round barrows.

In considering the role of the fenland in this period, it is important to acknowledge that inundation had for a long time been a feature of this area - some excavated round barrows show evidence of peat growth in their upper ring ditch fills from the later Bronze Age onwards (e.g. Evans et al. forthcoming). Prior to the early medieval period, however, it appears that most round barrows were still seen to occupy (or to constitute) workable land - they were used for ephemeral Iron Age camps, and were interwoven with Roman fields. Even in the early medieval period, the overall distribution of activity indicates that these wetlands - and in particular the islands 
within them - were settled and used for a range of purposes (see also Jackson \& Potter 1996; Lane \& Hayes 1993; Williams 2006, 206).

\section{The temporality of round barrow relationships}

As mentioned at the beginning of this paper, many existing studies of later practices at prehistoric monuments touch upon aspects of their temporality (their chronology, duration, intensity, etc.) and also the extent to which they can inform us about past peoples' historical understandings. Some time ago, Bradley (1987) challenged the idea that such activity represented straightforwardly ritual 'continuity' from the Bronze Age. Several authors have suggested that round barrows were, at different times, viewed as belonging to the 'near' or 'distant' past (e.g. Barrett 1999b; Semple 2013, 207). This distinction relates broadly to discussions about whether the kinds of historical understanding involved were 'genealogical' or 'mythical' in character (e.g. Barrett 1994, 1999b; Gosden \& Lock 1998, 6; Giles 2012, 53). It has also been suggested that certain prehistoric monuments accumulated meaning over the early medieval period (Semple 2013, 225). An extended study of round barrow relationships such as that undertaken here can contribute specifically to such discussions.

\section{Broad temporal patterning}

Viewed through the lens of traditional archaeological periods (the later Bronze Age, Iron Age, etc.), it was suggested above that there was an overall decline in the level of activity at round barrows over the duration of the study period. Once probed further, however, it is possible to identify subtleties within this general patterning - to gain a better sense of the ebb and flow of round barrow relationships over an extended timespan.

In order to do so, the timespans of later activities at round barrows were framed slightly differently using 'fuzzy' temporal modelling (Green 2011). Rather than 
assigning episodes of activity to traditional archaeological periods or even to subperiods, this approach takes account of the probability that the activity concerned belongs to 100-year time-slices within the overall study period. Very specifically dated activities - a pit containing assorted items of mid second-century AC date - are given a probability of 1 of belonging to the time-slice AC 100-200. For more vaguely dated activities - a later Bronze Age field ditch assigned to the period 1500-1100 BC - the probability is shared between the relevant 100 year time-slices (e.g. this example would have a probability of 0.25 of belonging to each of the time-slices 1500-1400 BC, 1400-1300 BC etc.). By summing the temporal probabilities of all of the later activities under consideration, a better understanding of the broad rhythm of such practices can be generated (Fig. 14). One important benefit of this method is that both vaguely and precisely dated activities can be considered together.

Viewed in this way, it is clear that relationships between round barrows and later activities were particularly intense in the Middle Bronze Age. Assessed at a period level, similar frequencies of activity were recorded at round barrows during both the Iron Age and Roman periods. Once these incidences are distributed over the timespans actually represented by these periods however (of roughly 800 and 400 years respectively), a distinct lull in Iron Age activity at round barrows is brought into sight. The apparent burgeoning of activity at round barrows in the Roman period relates partly to the fact that materials of this period are typically more closely dated and are thus are given greater weighting in the model. Even so, Roman activity at round barrows is perhaps more prevalent than has previously been recognized. It is also notable that, contrary to the broad chronology offered by Williams (1998a), activity at round barrows does not appear to have been a particular feature of the beginning and end of the Roman period. As discussed above, the overall lower incidence of early medieval activity at round barrow sites could relate to a range of factors, not least the immersion of many round barrows within the fenland at this time.

Characterizing specific historical trajectories 
In order to gain a better understanding of the tempo of activities undertaken at specific round barrow sites a record was made of the overall number of instances of activity identified, and how this activity was distributed over the study period according both to traditional archaeological periods and 'fuzzy' time slices. The aim here was to address the issue of whether, over the duration of the study period, certain sites became a particular focus of attention such that they gained heightened historical significance beyond the duration of single episodes of activity. It might, for instance, be envisaged that some round barrows sites were engaged with repeatedly (linked perhaps to their particular physical properties, their broader landscape associations, or to memories relating to previous activities undertaken at them), to the extent that they were selected preferentially as contexts for undertaking certain activities (e.g. Bradley 2002, 134; Semple 2013, 225).

More than one incidence of activity was identified at just over two thirds of round barrow sites that were engaged with purposefully (Fig. 15). In most of these cases more than one traditional period of activity is represented and the periods involved are often consecutive. It is important to stress, however, that this does not necessarily imply that these episodes of activity were directly sequential or related in any way. Indeed by plotting separately the summed 'fuzzy' probability of the timespan of later activity at each round barrow site (in 100-year time-slices), it is possible to generate a good impression of the truly sporadic rhythm of these practices (Fig. 16). Very occasionally, it is possible to suggest that certain round barrows or round barrow groups were meaningful in broadly coherent ways over periods potentially spanning several hundred years - see for example the evidence from Pode Hole Farm, Thorney for the later Bronze Age (Cooper 2016; Daniels 2009) and from the Raunds landscape for the Late Iron Age and Early Roman period (Crosby \& Muldowney 2011; Harding \& Healy 2007; Parry \& Blinkhorn 2006).

Significantly, however, none of the sites analysed for this study amassed later activity over the entire duration of the study period or even over large parts of it.

\section{Discussion}


Returning to the aims set out at the very beginning of this paper, I will finish by highlighting the main ways in which this study augments existing understandings of activities undertaken at round barrows in Britain between 1500 BC-AC 1086, and has been able to generate other types of meaning.

\section{Contextualising existing understandings}

At a general level this analysis contributes to existing investigations of later activity at prehistoric monuments in four main ways. Its considerable temporal scope spanning c. 2600 years - balances out a previous emphasis on scrutinizing single periods and mainly early medieval activity, at these features. The study's inclusive approach - taking into consideration all forms of activity undertaken at round barrows - adds important texture to accounts that have focused on more conspicuous or clearly definable practices (e.g. omitting the evidence represented by material traces or ephemeral pits). By placing the emphasis on relationships between round barrows and other forms of activity it has been possible to consider these features as active participants in the development of landscapes. The focus on a specific case study region that has not featured significantly in existing accounts, that has benefited from extensive recent archaeological investigation, and whose history is marked strongly by the shifting fenland at its core, responds to recent calls to operate at a detailed regional level (e.g. Semple 2013) and offers a unique perspective on this topic.

This account also contributes in specific ways to existing period-based studies. For later prehistory, a focused analysis of activities undertaken at round barrows has been offered for the first time - an important step in itself. The intensity of such practices in the later Bronze Age demonstrates emphatically that these features continued to play a vital role in landscapes of this period in various ways, contrary to some previous assertions (e.g. Brück 2000, 285; Bradley 2007, 201; Yates 2007, 93). Evidence for the Iron Age adds nuance to existing suggestions that round barrows played only a minimal role in landscapes of this period and provides important context for the evidence from Wessex and East Yorkshire (Barrett 1999b; Giles 2012). Iron Age activities at round barrows in the east of England were relatively rare. However these features were still caught up in a wide range of projects (settlement, 
trackways, temporary camps etc.). Much like other key contexts in this period - ditch terminals, pits, etc. (see for example Hill 1995) - round barrows also occasionally received unusual material deposits.

Significantly, this study's unique focus on both later Bronze Age and Iron Age activity suggests that a major rupture did take place in the character and frequency of practices undertaken at round barrows at the beginning of the first millennium BC. I am not convinced that this observation elucidates existing suggestions that round barrows were understood for the first time in the Iron Age as belonging to a past that was distanced or detached from living memory (Barrett 1999b, 262; Gosden \& Lock 1998, 11). Such arguments (together with the distinction that has been made between 'genealogical' and 'mythical' chronologies) played an important role in early archaeological discussions about prehistoric peoples' historical understandings. However like Greenhouse $(1996,96)$ and Lucas $(2005,94)$ I would argue that understandings of time are highly complex and mutable, defying simple generalizations. Nevertheless, the strong association that developed between round barrows, fields and funerary practices over the later Bronze Age did clearly dissipate in the Early Iron Age. The finding that whole and fragmentary items (and occasionally burials) were deposited persistently at round barrows over the duration of the Iron Age adds important empirical detail to previous suggestions that Iron Age depositional practices may have provided an important context for ritual activity in the Roman period (Eckardt et al. 2009, Hutton 2011, 15). It is certainly possible that the diffuse yet persistent deposits made at round barrows throughout the Iron Age set the scene for the construction of formal depositional contexts (shrines and temples) at round barrows in the Late Iron Age and Roman periods.

This investigation makes clear that Roman activity at round barrows in the east of England was both more prevalent and more diverse than has previously been suggested. By taking an inclusive approach it was possible to add texture to existing arguments regarding the character of this activity. Alongside more conspicuous depositional practices, round barrows were commonly a focus for subtler material deposits including fragments of seemingly quite ordinary objects. This finding broadens both Williams' (2000) arguments regarding the 'ritual' emphasis of Roman activities at round barrows (Williams' definition of deposits representing ritual activity 
might productively be extended), and Hutton's observations regarding the 'everyday' character of Roman material deposits at caves and prehistoric monuments in southwest England and the Peak District (this argument potentially applies more widely). The study also highlights certain regional specificities. In contrast to patterning identified at a national level, Roman burials at round barrows are rare in the east of England and Roman coin hoards are not an important aspect of the depositional repertoire encountered at these features.

In some ways, the makeup of early medieval activity at round barrows in the east of England conformed largely to the findings of existing studies. Again, however, the long-term emphasis of this study allowed further light to be cast on the relationship between early medieval practices at round barrows and those undertaken in earlier periods. Contrary to some existing observations (e.g. Williams 1998a, 77; 2006, 182) there was no strong evidence to suggest that early medieval activity at round barrows developed directly from Late Roman traditions. Rather the marked funerary emphasis of early medieval deposits at round barrows in the east of England can be contrasted with the material emphasis of deposits made in the Roman period. Another key, regionally-specific finding was the overall 'marginal' character of activities undertaken at round barrows in the study area. Round barrows were often overlooked in the siting of early medieval cemeteries and many of them were made inaccessible by the encroaching fenland.

\section{Opening up new interpretative possibilities}

A substantial part of the account given here is necessarily descriptive - one key analytical aim was to expose the subtlety and diversity of practices carried out at round barrows and to interrogate the assumption that these activities were undertaken primarily according to a common and well-trodden set of rationale. It is certainly possible that the interpretative uniformity of existing accounts of later activity at prehistoric monuments relates to their theoretical emphasis on explaining the existence of such practices - an emphasis that relies heavily on the use of (ethnographic and documentary) analogical sources. This approach has arguably 
masked subtleties within the evidence and precluded the development of interpretations that make full use of the particularities of practices encountered at prehistoric monuments. The explicitly empirical approach taken here, together with the methodological emphasis on examining relationships between round barrows and other aspects of landscape over an extended time period, has opened up new interpretative ground in two main ways: it has cast particular light on the temporal qualities of later activities at round barrows, and on how we understand the category 'round barrow'.

The detailed consideration of the temporal qualities of later activities at round barrows offered here extends significantly recent attempts to explore round barrow chronologies for the Early Bronze Age in Britain (e.g. Garwood 2007, Garrow et al. 2014). Two main ruptures were identified in the incidence of practices undertaken at round barrows - at the start of the first millennium BC and at the end of the Roman period. In particular it appears that there was a marked lull in activity at round barrows during much of the first millennium $\mathrm{BC}$ - a passing but considerable hiatus that is interesting in itself. Broad consistencies over extended time periods were also highlighted - for instance in the broad character of material deposits made at round barrows in the Iron Age, Roman and (to a lesser extent) early medieval periods. Additionally the temporal complexities of practices enacted at round barrows - both for us in interpreting the evidence, and also potentially for people in the past - were foregrounded. Episodes of activity of different dates and durations were condensed at round barrows. Assemblages of items with various origins (e.g. disparate coin collections, Roman grave goods with early medieval burials) were also deposited in round barrows. Overall, the sporadic character of history-making at round barrows was emphasized. Only very occasionally is it possible to trace links between activities carried out at round barrows within specific landscape areas over longer periods (potentially spanning several hundred years).

By examining relationships between round barrows and other landscape elements over an extended time period, long-term understandings both of 'round barrows' and of later activities enacted in their vicinity have been illuminated. It is therefore possible to address directly Holtorf's (2002) contention that biographical monument studies (including his own 1998 study) assume problematically that prehistoric 
monuments can operate as stable analytical foci over extended time periods. Obviously at one level, this study has treated round barrows as coherent analytical objects - it has scrutinized in detail both the character of activities undertaken at 'round barrows' and their role in shaping landscape histories. Only by doing so, however, and by making 'relationships' a key investigative focus, has it been possible also to interrogate the shifting constitution of this analytical entity.

Significantly, the prevalence of later activity at round barrows across the study period challenges previous tendencies to view these monuments as Early Bronze Age features that were 're-used' in later periods (see Cooper 2016 for a further discussion of this issue $)^{12}$. Many 'round barrows' have retained similar physical forms since the Early Bronze Age - in this sense they do comprise a readily recognizable, stable and discrete category. However as papers in Last (2007a) show very clearly, the processes by which these seemingly similar monumental forms were created over the late third and early second millenniums BC vary hugely: it seems very unlikely that 'round barrows' had a coherent, constant identity even in the Early Bronze Age. The practices undertaken at round barrows over the period discussed here can therefore be seen as contributing to a diverse range of processes through which the category 'round barrow' has been (and still is) produced since at least the late third millennium BC.

It is also possible to identify several specific stages during the study period at which the coherent identity of 'round barrows' was arguably challenged. It was suggested above that quite specific (physical, formal, material and spatial) relationships were established between fields and round barrows in the Middle Bronze Age. Further to this, it is worth noting that both round barrows and field systems were foci for similar sets of funerary and depositional activities during this period (see also Cooper 2016). Consequently it is certainly possible that distinctions between the categories 'round barrow' and 'field' were in some ways blurred in the Middle Bronze Age. During the Iron Age and Roman periods, the physical survival of round barrows was more commonly under threat. Some round barrows were made invisible by settlement activity and by route building. Others were transformed physically by activities that may well initially have been intended to augment their qualities (e.g. building temples and shrines). One consequence of this process is that the origin of these features as 
'round barrows' may ultimately have been obscured. The identity of 'round barrows' was potentially tested in a slightly different way in the early medieval period. Several factors indicate that round barrows were recognized specifically and possibly also developed more coherent meanings at this time: activities undertaken at round barrows were fairly consistent, new round barrows were created, and round barrows were identified explicitly in early medieval written sources. However it could also be argued that the similar treatment of 'new' and 'existing' round barrows in the early medieval period created a new hybrid (in terms of their origins) monument category. In this context, it is interesting to note there is little convincing evidence to suggest that 'old' and 'new' round barrows were distinguished between linguistically in the early medieval period (Semple 2013, 158).

This study has taken one important step towards developing interpretations of activity at prehistoric monuments following their initial construction and use that do not return ultimately to a narrow set of widely-used and increasingly generic explanations - the ideas that prehistoric monuments were engaged with primarily because they had ancestral, supernatural and/or historical associations, and that the main reasons for engaging with them were in order to foster local identities/senses of place, to legitimize land rights, and to validate the rise of new social and political orders. I am not suggesting that these themes should be avoided entirely. Rather, that they should be raised only when it is possible to add meaningfully to the broad arguments that have already been made - for instance to illuminate the particular kinds of social identities that were being expressed during practices at round barrows, or to argue convincingly that communities undertaking certain activities at round barrows were concerned specifically with negotiating land rights. More importantly, it is vital that other interpretative pathways are explored. Practices undertaken at round barrows are variable throughout the period under consideration here. This should challenge us to develop approaches that embrace this diversity and seek out potentially meaningful patterning within it. Hopefully this analysis will spark further work in this vein at a range of temporal and spatial scales. 


\section{Notes}

${ }^{1}$ Extensive cemeteries of small funerary mounds that developed across north-west Europe in the later Bronze and Iron Ages.

2 Throughout this study, 'round barrow' is used as a coverall term for both 'round barrows' and 'ring ditches'. These may well have constituted separate monument forms that operated in different ways over the study period (Evans et al. forthcoming). However ploughed out 'round barrows' present themselves in excavation as 'ring ditches' - it is only rarely possible to tell whether the absence of a mound during excavation equates to the absence of a mound in prehistory. Consequently they are treated together here.

${ }^{3}$ Eighth to tenth-century AC churches are a notable exception to this pattern since these are much more commonly associated with Romano-British sites and, to a lesser extent, with prehistoric enclosures (e.g. Semple 2013, 128-32).

4 Throughout the analysis, the term 'excavated round barrow' denotes round barrows that have been verified by any form of intrusive fieldwork - full excavation, partial excavation, trial trenching, watching briefs, test pits, coring, etc.. It is also worth noting that round barrow 'sites' (as in coherent 'groups' of round barrows) are notoriously difficult to define (e.g. Bourgeois 2013, 13-4). This is particularly the case in the east of England where round barrows are often widely spaced over extensive areas, conforming to definitions for 'dispersed' or 'area' barrow cemeteries (Fleming 1971, 141). In most cases the round barrow sites identified for this study were clear-cut. Within extensive excavated landscapes that included several possible groupings of round barrows (e.g. at Raunds and at Barleycroft/Over), separate sites were defined where individual round barrows or round barrow groups were spatially distinct or where they were isolated topographically (e.g. they were located on an island); see Bourgeios $(2013,142-8)$ for an exploration of round barrow intervisibility and the possibility that groupings within more extensive barrow landscapes might usefully be defined on this basis.

${ }^{5}$ See Appendix 1 for a full list of excavated round barrow sites examined in detail. Wherever possible, the source_ID given for round barrow groups included in this list is that for the entire group (sources_IDs for individual round barrows or subsets of barrows within the overall group are provided in the 'Associated source_ID' column). Where no source_ID was available for the overall round barrow group the identifier given in the source_ID column is that for one round barrow of the group. The source_IDs for other round barrows in the same group are given in the 'Associated source_ID' column. It is also worth noting that 31 of these round barrow sites were represented in more than one of the consulted data sources. In these cases, the Source_ID given in Appendix 1 is preferentially the HER ID. Source IDs from the NRHE, OASIS and the BIAB are given only where the round barrow site was not represented by an HER record. No directly relevant source ID was identified for the segmented ditch circle at Stanwick - the Source_ID given for this monument in Appendix 1 is actually that for the immediately adjacent Neolithic causewayed ring ditch. Overall, the structure of these data is necessarily complicated. This relates to the complex histories via which evidence relating to round barrows has been produced and recorded over at least a 150-year period (Cooper \& Green 2016). The full dataset will be available via the ADS from 2017, following completion of the EngLaID project.

${ }^{6}$ Only 91 of the 173 digital records relating to excavated round barrows in the study area were linked to reports that were both accessible and potentially included sufficiently detailed information. Many round barrow sites in Suffolk and Norfolk were excavated in the late $19^{\text {th }}$ and early $20^{\text {th }}$ centuries - no formal report was produced. Several of the excavated round barrow sites for which reports were accessible were investigated only very minimally (e.g. during trial trenching or watching briefs) - the information available for these sites was too basic to merit detailed consideration.

${ }^{7}$ These figures relate to investigated (and thus verified) round barrows only. Since excavations themselves have a specific set of topographic and cultural associations (e.g. they are frequently 
undertaken in advance of gravel extraction and thus also tend to be located along major river valleys) they cannot be seen as representative of all potential round barrows.

${ }^{8}$ See Appendix 3 for an explanation of how later activities were grouped into practice-based classes for the purpose of this analysis.

${ }^{9}$ It is important to be cautious in reading this plot. Since traces of later Bronze Age activity are typically subtler than those for the Iron Age and Roman periods, they are more likely than the latter to be identified through excavations rather than through other prospection methods. Consequently the known spatial distribution of later Bronze Age activity is likely to correspond more closely with that of excavated sites. Having said this the same argument could be made for early medieval remains which are also notoriously difficult to find. On this basis, it seems likely that the discrepancy that is evident in Figure 5 between the strong spatial correspondence of records of later Bronze Age activity and records of excavated round barrows, and the weaker spatial correspondence between records of early medieval activity and records of excavated round barrows does have some substance.

10 The particular emphasis on developing sizeable later Bronze Age cremation cemeteries at round barrows in the Great Ouse Valley is evident even if evidence well beyond the dataset examined in detail here is considered (Cooper 2016; see also Evans \& Appleby 2008 for the only other - rather exceptional - example within the study area of a later Bronze Age cremation cemetery comprising more than 10 burials at a round barrow).

${ }^{11}$ A square cropmark that encloses one round barrow was not located in an investigative trial trench (Fennell 1961). A pit cut into the top of another round barrow produced fragmentary human remains that were radiocarbon-dated to the Iron Age. At the time, however, the date was dismissed as being erroneous (Simpson 1976).

12 The term 're-use' is avoided specifically throughout this study. This term has been used widely to discuss a range of later activity at prehistoric monuments and is a handy and well-understood shorthand term for researchers in this field. However I would argue that it has sometimes been used quite unquestioningly (for instance I am unsure as to whether the construction of an early medieval settlement close to a round barrow cemetery can be seen as constituting 're-use' e.g. Crewe 2012). Additionally this term arguably objectifies round barrows (and other prehistoric monuments) in an unhelpful way - presenting them straightforwardly as objects that humans did things to rather than as morphing and active agents. 


\title{
Acknowledgements
}

This study was conducted as part of the European Research Council-funded English Landscape and Identities Project (Project Ref. 269797), University of Oxford. The data were collated from Cambridgeshire, Norfolk, Northamptonshire, Peterborough, and Suffolk HERs, Historic England's Excavation Index and National Record of the Historic Environment, the Archaeological Investigations Project, the Archaeological Data Service and the Portable Antiquities Scheme. It goes without saying that this study would not have been possible without the support and expertise of the many professionals involved in first curating and then extracting these data for the EngLaID project. I am especially grateful to Sally Croft (Cambridgeshire HER), Christine Addison (Northamptonshire HER), Sarah Botfield and Rebecca Casa-Hatton (Peterborough HER), Richard Hoggett (Suffolk HER) and Heather Hamilton (Norfolk HER) who offered advice on the specificities of their data and provided supplementary information. The study has benefited greatly from discussions with archaeologists from Cambridge Archaeological Unit (Grahame Appleby, Chris Evans, Mark Knight), Phoenix Consulting Archaeology Limited (Gary Coates) and Suffolk Archaeology (Jo Caruth). Fraser Sturt (Southampton University) provided images of the prehistoric fenland taken from his published models of North West European Holocene palaeogeography and inundation (Sturt et al. 2013). Ed Caswell (Durham University), Chris Evans and Iona Robinson (Cambridge Archaeological Unit) generously shared unpublished material with me. The ideas put forward were developed through discussions with other members of the EngLalD project team Miranda Creswell, Vicky Donnelly, Tyler Franconi, Chris Gosden, Chris Green, Letty Ten Harkel, Sarah Mallet, Laura Morley and Dan Stansbie. Chris Green also undertook the data processing for Figures 6 and 13. Finally I would like to thank Duncan Garrow, Chris Gosden, Chris Green, Letty Ten Harkel and the two anonymous reviewers for their helpful comments on earlier versions of this text.

\author{
Anwen Cooper \\ Institute of Archaeology \\ University of Oxford \\ 34 Beaumont Street \\ Oxford OX1 2PG \\ UK
}

Email: anwen.cooper@arch.ox.ac.uk, anwenc@gmail.com 


\section{References}

Aitchison, N.B. 1988. Roman wealth, native ritual: coin hoards within and beyond Roman Britain. World Archaeology 20, 270-83.

Artelius, T. 2013. Inventions of memory and meaning: examples of Late Iron Age reuse of Bronze Age monuments in south-western Sweden, in Beyond Barrows:

Current Research on the Structuration and Perception of the Prehistoric Landscape Through Monuments, ed. D. Fontijn. Leiden: Sidestone Press, 21-39.

Baker, J., S.J. Brookes \& A. Reynolds forthcoming. Landscapes of Governance: Legal Geographies and Political Order in Anglo-Saxon England, AC 400-1066.

Barlow, G. 2008. Proposed processing plant, Elton Estate, Northamptonshire. A 'strip map and sample' archaeological investigation. Interim site narrative. Bury St Edmonds: Archaeological Solutions Ltd., Report no. 3009.

Barrett, J. 1999a. Chronologies of landscape, in The Archaeology and Anthropology of Landscape, eds. P. Ucko, R. Layton. London: Routledge, 21-30.

Barrett, J. 1999b. The mythical landscapes of the British Iron Age, in Archaeologies of Landscape, eds. W. Ashmore, B. Knapp. Oxford: Blackwell, 253-68.

Barrett, J. 1994. Fragments from Antiquity: An Archaeology of Social Life in Britain, 2900-1200 BC. Oxford: Blackwell.

Barrett, J.C. 1990. The monumentality of death: the character of Early Bronze Age mortuary mounds in southern Britain. World Archaeology 22 (2), 179-89.

Bates, S. 2008. An archaeological evaluation at Crimplesham Replacement Quarry. Norwich: NAU Archaeology, Report no. 1754.

Van Beek, R. \& G. De Mulder 2014. Circles, cycles and ancestral connotations. The long-term history and perception of late prehistoric barrows and urnfields in Flanders (Belgium). Proceedings of the Prehistoric Society 80, 299-326.

Blair, J. 1995. Anglo-Saxon pagan shrines and their prototypes. Anglo-Saxon Studies in Archaeology and History 8, 1-28.

Blair, J. 2005. The Church in Anglo-Saxon Society. Oxford: Oxford University Press.

Bourgeois, Q. 2013. Monuments on the horizon: the formation of the barrow landscape throughout the 3rd and 2nd millennium BC. Unpublished PhD thesis: University of Leiden.

Bradley, R. 2007. The Prehistory of Britain and Ireland. Cambridge: Cambridge University Press.

Bradley, R. 1993. Altering the Earth: The Origins of Monuments in Britain and Continental Europe. Edinburgh: Society of Antiquaries of Scotland. 
Bradley, R. 1987. Time regained: the creation of continuity. Journal of the British Archaeological Association 140 (1), 1-17.

Bradley, R. 2002. The Past in Prehistoric Societies. London: Routledge.

Brück, J. 2000. Settlement, landscape and social identity: the Early-Middle Bronze Age transition in Wessex, Sussex and the Thames Valley. Oxford Journal of Archaeology 19(3), 273-300.

Brookes, S. 2007. Economics and Social Change in Anglo-Saxon Kent AC 400-900: Landscapes, Communities and Exchange. (BAR British Series 431.) Oxford: Archaeopress.

Caruth, J. forthcoming. The Anglo-Saxon Burial Grounds at RAF Lakenheath, Eriswell, Suffolk. Norwich: East Anglian Archaeology.

Caruth, J. \& S. Anderson 2005. An assessment of the potential for analysis and publication for archaeological work carried out at RAF Lakenheath between 1987 and June 2005. Volume 1: The Anglo-Saxon cemeteries ERL 104, ERL 046, and ERL 114. Bury St Edmunds: Suffolk County Council Archaeological Services, Report no. 2005 / 94.

Caswell, E. 2013. Bodies, burnings and burials. Analysing Middle Bronze Age cremations in Britain. Unpublished MA thesis: University of Durham.

Chadwick, A.M. 2016. Foot-fall and hoof-hit. Agencies, movements, materialities, and identities; and later prehistoric and Romano-British trackways. Cambridge Archaeological Journal 26 (1), 93-120.

Chapman, A. 2010. West Cotton, Raunds: A Study of Medieval Settlement Dynamics, AC 450-1450. Excavation of a Deserted Medieval Hamlet in Northamptonshire, 1985-89. Oxford: Oxbow Books.

Chester-Kadwell, M. 2009. Early Anglo-Saxon Communities in the Landscape of Norfolk. (BAR British Series 481.) Oxford: Archaeopress.

Cohen, A. 1985. The Symbolic Construction of Community. Chichester: Ellis Horwood.

Connerton, P. 1989. How Societies Remember. Cambridge: Cambridge University Press.

Cooper, A. 2016. 'Held in place'? Round barrows in the later Bronze Age of lowland Britain. Proceedings of the Prehistoric Society 82.

Cooper, A. \& C. Green 2016. Embracing the complexities of 'big data' in archaeology: the case of the English Landscape and Identities project. Journal of Archaeological Method and Theory 
Craven, J. 2004. The Sandpits, Station Road, Lakenheath LKH220. A report on the archaeological excavations, 2002. Bury St Edmunds: Suffolk County Council Archaeological Services, Report no. 2004 / 26.

Craven, J. 2012. Liberty Village, RAF Lakenheath, Eriswell. ERL 143; ERL 147; ERL 148 \& ERL 203. Archaeological Assessment Report. Bury St Edmunds: Suffolk County Council Archaeological Services, Report no. 2012 / 038.

Crewe, V. 2012. Living With the Past: The Reuse of Prehistoric Monuments in AngloSaxon Settlements. (BAR British Series 573.) Oxford: Archaeopress.

Crosby, V. \& L. Muldowney 2011. Stanwick Quarry, Northamptonshire: Raunds area project: phasing the Iron Age and Romano-British settlement at Stanwick, Northamptonshire (excavations 1984-1992): archaeological report. Portsmouth: English Heritage.

Cunnington, R.H. 1975. From Antiquary to Archaeologist: A Biography of William Cunnington, 1754-1810. Princes Risborough: Shire Publications.

Daniel, P. 2009. Archaeological excavations at Pode Hole quarry: Bronze Age occupation on the Cambridgeshire Fen-edge. (BAR British Series 484.) Oxford: Archaeopress.

Dark, P. 1993. Roman-period activity at prehistoric ritual monuments in Britain and the Armorican peninsula, in Theoretical Roman Archaeology: First Conference Proceedings, University of Newcastle 1991, ed. E. Scott. Aldershot: Avebury, 13-46.

Eckardt, H. \& H. Williams. 2003. Objects without a past? in Archaeologies of Remembrance: Death and Memory in Past Societies, ed. H. Williams. New York, London: Kluwer Academic / Plenum Publishers, 141-70.

Eckardt, H., P. Brewer, S. Hay \& S. Poppy 2009. Roman Barrows and their Landscape Context: a GIS Case Study at Bartlow, Cambridgeshire. Britannia 40, 6598.

Ellis, P., G. Coates, R. Cuttler, \& C. Mould. 2001. Four sites in Cambridgeshire: Excavations at Pode Hole Farm, Paston, Longstanton and Bassingbourn, 1996-7. (BAR British Series 322.) Oxford: Archaeopress.

English, J. 2013. Pattern and Progress: Field Systems of the Second and Early First Millennia BC in Southern Britain. (BAR British Series 587.) Oxford: Archaeopress.

Evans, C. 1985. Tradition and the cultural landscape: an archaeology of place. Archaeological Review from Cambridge 4 (1), 80-94.

Evans, C. \& G. Appleby 2008. Historiography and fieldwork: Wyman Abbott's great Fengate ring-ditch (a lost manuscript found). Proceedings of the Prehistoric Society 74, 171-92. 
Evans, C., J. Tabor \& M. Vander Linden forthcoming. Twice-crossed River: Prehistoric and Palaeoenvironmental Investigations at Barleycroft Farm / Over, Cambridgeshire (The Archaeology of the Lower Ouse Valley, Volume III). Cambridge: Cambridge Archaeological Unit.

Evans, C., G. Appleby, S. Lucy, \& R. Regan 2013. Romano-British Communities at Colne Fen, Earith: An Inland Port and Supply Farm. Cambridge: Cambridge Archaeological Unit.

Evans, C. \& I. Hodder 2006. Marshland Communities and Cultural Landscapes from the Bronze Age to the Present Day. Cambridge: MacDonald Institute for Archaeological Research.

Fennell, K.R. 1961. Excavations at O.S. 38, Tallington. Lincolnshire Architectural and Archaeological Society Reports and Papers 9 (1), 26-34.

Fleming, A. 1971. Territorial patterns in Bronze Age Wessex. Proceedings of the Prehistoric Society 37, 138-66.

Fokkens, H. 2012. Access to origins: about the meaning of continuity and discontinuity in the use of barrow 'cemeteries' in Gräberlandschaften der Bronzezeit. Internationales Kolloquium zur Bronzezeit, Herne, 15-18 Oktober 2008, eds. D. Bérenger, J. Bourgeios, M. Talon \& S. Wirth. Darmstadt: Von Zabern, 700.

Fokkens, H. \& S. Arnoldussen 2008. Bronze Age settlements in the Low Countries: an overview, in Bronze Age Settlements in the Low Countries, eds. S. Arnoldussen, H. Fokkens. Oxford: Oxbow books, 17-40.

Fontijn, D. 1996. Socialising landscape: second thoughts about the cultural biography of urnfields. Archaeological Dialogues 3 (1), 77-87.

Garrow, D., J. Meadows, C. Evans \& J. Tabor 2014. Dating the dead: a highresolution radiocarbon chronology of burial within an Early Bronze Age barrow cemetery at Over, Cambridgeshire. Proceedings of the Prehistoric Society 80, 20736.

Garwood, P. 2007. Before the hills in order stood: chronology, time and history in the interpretation of Early Bronze Age round barrows, in Beyond The Grave: New Perspectives on Barrows, ed. J. Last. Oxford: Oxbow Books, 30-52.

Gerritsen, F. 2003. Local Identities: Landscape and Community in the Late Prehistoric Meuse-Demer-Scheldt Region. Amsterdam: Amsterdam University Press.

Gerritsen, F. 2007. Familiar landscapes with unfamiliar pasts? Bronze Age barrows and Iron Age communities in the southern Netherlands, in The Earlier Iron Age in Britain and the Near Continent, eds. C. Haselgrove \& R. Pope. Oxford: Oxbow Books, 338-53.

Gibson, D. \& M. Knight. 2002. Prehistoric and Roman archaeology at Stonald Field King's Dyke West, Whittlesey: Monuments and settlement. Cambridgeshire: Cambridge Archaeological Unit, Report no. 498. 
Giles, M. 2012. A Forged Glamour: Landscape, Identity and Material Culture in the Iron Age. Oxford: Oxbow.

Gosden, C. \& G. Lock 1998. Prehistoric histories. World Archaeology 30 (1), 2-12.

Green, C. 2011. Winding Dali's Clock: The Construction of a Fuzzy Temporal-GIS for Archaeology. (BAR International Series 2234.) Oxford: Archaeopress.

Greenhouse, C. J. 1996. A Moment's Notice: Time Politics Across Culture. London: Cornell University Press.

Hall, D., C. Evans, I. Hodder \& F. Pryor 1987. The Fenlands of East Anglia, England: Survey and Excavation, in European Wetlands in Prehistory, eds. J. Coles \& A. Lawson. Oxford: Clarendon Press, 169-201.

Hall, D. 1992. The Fenland Project Number 6: The South-western Cambridgeshire Fenlands. Cambridge: Cambridgeshire Archaeological Committee; Fenland Project Committee; Scole Archaeological Committee.

Hall, D. \& J. Coles 1994. Fenland Survey: An Essay in Landscape and Persistence. London: English Heritage.

Hamerow, H. 2006. 'Special deposits' in Anglo-Saxon settlements. Medieval Archaeology 50, 1-30.

Harding, J \& F. Healy 2007. A Neolithic and Bronze Age Landscape in Northamptonshire. Swindon: English Heritage.

Healy, F \& J. Harding 2007. A thousand and one things to do with a round barrow, in Beyond The Grave: New Perspectives on Barrows, ed. J. Last. Oxford: Oxbow Books, 53-71.

Hill, J.D. 1995. Ritual and Rubbish in the Iron Age of Wessex: A Study on the Formation of a Specific Archaeological Record. (BAR British Series 242.) Oxford: Tempus Reparatum.

Hingley, R. 2009. Esoteric knowledge: ancient bronze artefacts from Iron Age contexts. Proceedings of the Prehistoric Society 75, 143-66.

Hingley, R. 1996. Ancestors and identity in the later prehistory of Atlantic Scotland: the reuse and reinvention of Neolithic monuments and material culture. World Archaeology 28 (2), 231-43.

Holtorf, C.J. 1998. The life-histories of megaliths in Mecklenburg-Vorpommern (Germany). World Archaeology 30 (1), 23-38.

Holtorf, C.J. 2002. Excavations at Monte da Igreja near Évora (Portugal). From the life-history of a monument to re-uses of ancient objects. Journal of Iberian Archaeology 4, 177-201. 
Hutton, R. 2011. Romano-British reuse of prehistoric ritual sites. Britannia 42, 1-22.

Jackson, R. \& T. Potter 1996. Excavations at Stonea, Cambridgeshire, 1980-85.

London: British Museum.

Johnston, R. 2001. 'Breaking new ground': land, tenure and fieldstone clearance during the Bronze Age, in Bronze Age Landscapes: Tradition and Transformation, ed. J. Brück. Oxford: Oxbow Books, 99-109.

Johnston, R. 2005. Pattern without a plan: rethinking the Bronze Age coaxial field systems on Dartmoor, south-west England. Oxford Journal of Archaeology 24 (1), 121.

Lane, T. \& P. Hayes. 1992. The Fenland Project Number 5: Lincolnshire Survey. The South-west Fens. Sleaford: Heritage Trust of Lincolnshire; Fenland Project Committee; Scole Archaeological Committee.

Last, J. (ed.) 2007a. Beyond The Grave: New Perspectives on Barrows. Oxford: Oxbow Books.

Last, J. 2007b. Covering old ground: barrows as closures, in Beyond The Grave: New Perspectives on Barrows, ed. J. Last. Oxford: Oxbow Books, 156-75.

Lucas, G. 2005. The Archaeology of Time. London: Routledge.

Lucy, S. 1992. The significance of mortuary ritual in the political manipulation of the landscape. Archaeological Review from Cambridge 11 (1), 93-105.

Lucy, S. 2000. The Anglo-Saxon Way of Death: Burial Rites in Early England. Stroud: Sutton.

Lucy, S. 1998. The Early Anglo-Saxon Cemeteries of East Yorkshire: An Analysis and Reinterpretation. (BAR British Series 272.) Oxford: John and Erica Hedges.

Meaney, A.L. 1964. A Gazetteer of Early Anglo-Saxon Burial Sites. London: Allen \& Unwin.

Parry, S. \& P. Blinkhorn 2006. Raunds Area Survey: An Archaeological Study of the Landscape of Raunds, Northamptonshire 1985-94. Oxford: Oxbow Books.

Penn, K. 1998. An Anglo-Saxon cemetery at Oxborough, West Norfolk: Excavations in 1990. Gressenhall: Norfolk Museums Service.

Percival, J. \& G. Trimble 2008. Excavations at Crow Hall Park, London Road, Downham Market, 1999-2000. Norfolk Archaeology XLV (III), 293-336.

Petts, D. 2002. Cemeteries and boundaries in western Britain, in Burial in Early Medieval England and Wales, eds. S. Lucy, A. \& Reynolds. London: Society for Medieval Archaeology, 24-46. 
Reynolds, A. 2002. Burials, boundaries and charters in Anglo-Saxon England: A reassessment, in Burial in Early Medieval England and Wales, eds. S. Lucy, \& A. Reynolds. London: Society for Medieval Archaeology, 171-94.

Reynolds, A. 1999. Later Anglo-Saxon England: Life and Landscape. Stroud: Tempus Publishing Ltd.

Reynolds, A. 2009. Anglo-Saxon Deviant Burial Customs. Oxford: Oxford University Press.

Robinson, I. 2007. Middle Bronze Age cremation practice in East Anglia: continuity and change in cemetery form and development. Unpublished MA thesis: University of Cambridge.

Roymans, N. \& F. Gerritsen 2002. Landscape, ecology and mentalités. A long-term perspective on developments in the Meuse-Demer-Scheldt region. Proceedings of the Prehistoric Society (68), 257-87.

Roymans, N. 1995. The cultural biography of urnfields and the long-term history of a mythical landscape. Archaeological Dialogues 2 (1), 2-24.

Semple, S. 2013. Perceptions of the Prehistoric in Anglo-Saxon England: Religion, Ritual, and Rulership in the Landscape. Oxford: Oxford University Press.

Semple, S. 1998. A fear of the past: the place of the prehistoric burial mound in the ideology of middle and later Anglo-Saxon England. World Archaeology 30 (1), 10926.

Semple, S. 2004. Locations of assembly in Early Anglo-Saxon England, in Assembly Places and Practices in Medieval Europe, eds. A. Pantos, \& S. Semple. Dublin: Four Courts Press, 135-54.

Semple, S. 2004. Recycling the past: ancient monuments and changing meanings in early medieval Britain, in Antiquaries and Archaists, the Past in the Past, the Past in the Present, eds. M. Aldrich, \& R. Wallis. Reading: Spire Books Ltd., 135-54.

Shephard, J. 1979. The social identity of the individual in isolated barrows and barrow cemeteries in Anglo-Saxon England, in Space Hierarchy and Society: Interdisciplinary Studies in Social Area Analysis eds. B.C. Burnham \& J Kingsbury. (BAR International Series 59.) Oxford: BAR, 47-80.

Simpson, W.G. 1976. A barrow cemetery of the second millennium BC at Tallington, Lincolnshire. Proceedings of the Prehistoric Society 42, 251-39.

Stoertz, C. 1997. Ancient Landscapes of the Yorkshire Wolds. Swindon: Royal Commission on the Historic Monuments of England. 
Vermeulen, F. \& J. Bourgeois 2000. Continuity of prehistoric burial sites in the Roman landscape of Sandy Flanders, in Burial, Society and Context in the Roman World, eds. M. Millett, M. Struck. Oxford: Oxbow, 143-61.

Waller, M. 1994. The Fenland Project Number 9: Flandrian Environmental Change in Fenland. Cambridge: Cambridgeshire Archaeological Committee; Fenland Project Committee; Scole Archaeological Committee.

Webster, L. 1999. The iconographic programme of the Frank's Casket, in Northumbria's Golden Age, eds. J. Hawkes \& S. Mills. Stroud: Sutton, 227-46.

Whitley, J. 2002. Too many ancestors (Archaeological interpretation). Antiquity 76 (291), 119-26.

Wickstead, H. 2008. Theorising Tenure: Land Division and Identity in Later Prehistoric Dartmoor, South-West Britain. (BAR British Series 465.) Oxford: Archaeopress.

Williams, H. 1997. Ancient landscapes and the dead: The reuse of prehistoric and Roman monuments as early Anglo-Saxon burial sites. Medieval Archaeology 41, 132.

Williams, H. 1998a. The ancient monument in Romano-British ritual practices, in TRAC 1997: Proceedings of the Seventh Annual Theoretical Roman Archaeology Conference, Nottingham 1997, eds. C. Forcey, J. Hawthorne \& R. Witcher. Oxford: Oxbow Books, 71-86.

Williams, H. 1998b. Monuments and the past in early Anglo-Saxon England. World Archaeology 30 (1), 90-108.

Williams, H. 2003. Archaeologies of Remembrance: Death and Memory in Past Societies. New York, London: Kluwer Academic / Plenum Publishers.

Williams, H. 2006. Death and Memory in Early Medieval Britain. Cambridge: Cambridge University Press.

Wymer, J. 1996. The excavation of a ring-ditch at South Acre, in Barrow Excavations in Norfolk 1984-1988, ed. J. Wymer. Dereham: Norfolk Museum Service, 58-89.

Yates, D. 2007. Land, Power and Prestige: Bronze Age Field Systems in Southern England. Oxford: Oxbow Books. 


\section{Author biography}

Anwen Cooper is the prehistoric researcher on the English Landscape and Identities project, University of Oxford. Her research interests include later prehistoric northwest Europe and theories about material culture, landscape, and archaeological practice. 'Held in place' (Proceedings of the Prehistoric Society 2016) considers round barrows in later Bronze Age landscapes. 


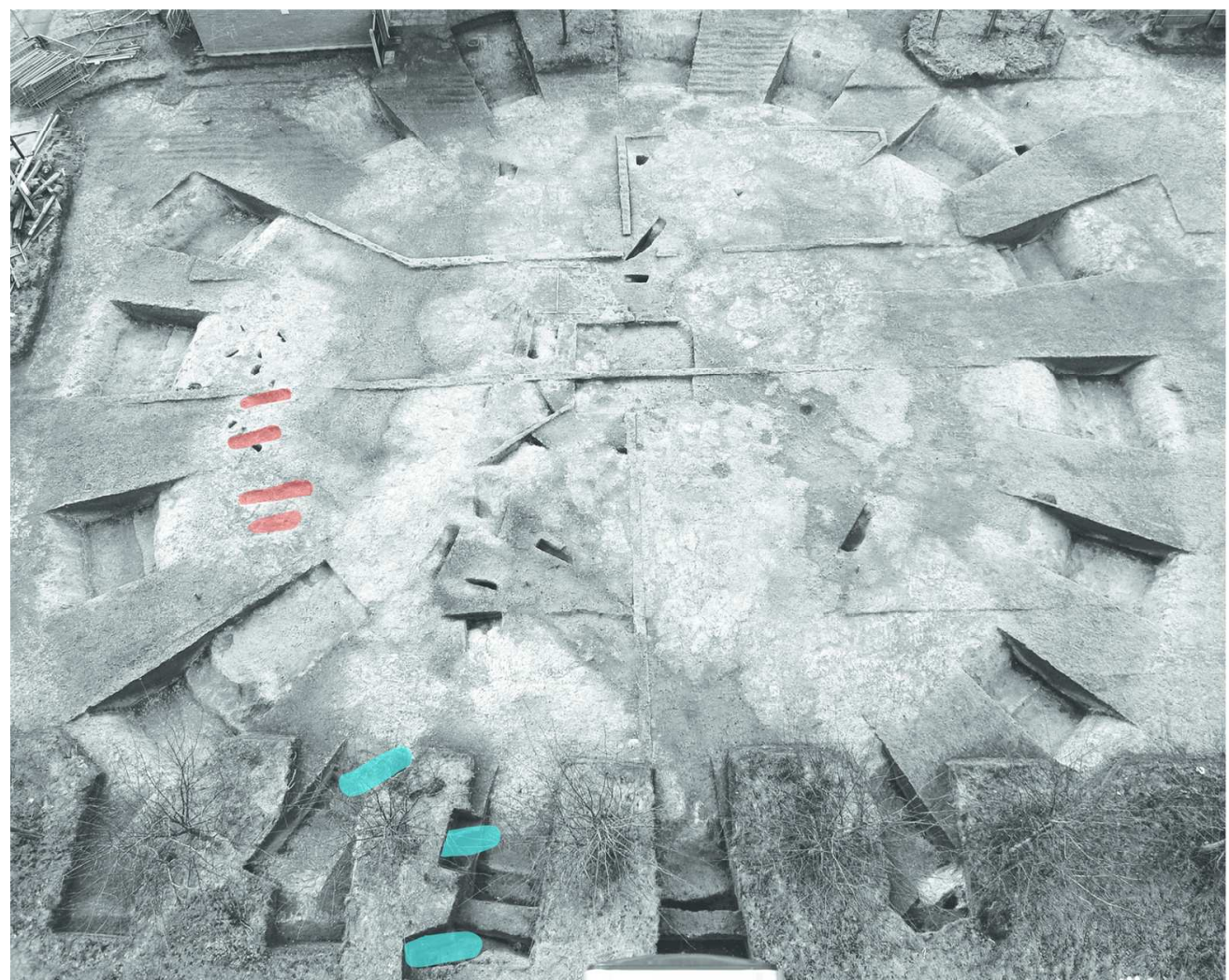

Figure 12. Late seventh/early eighth-century AD graves cut into a round barrow at Liberty Village (ERL 203), Eriswell, Suffolk (c) Suffolk Archaeology. The position of graves cut into the excavated ditch is marked in blue. That of graves cut into the remnant mound is marked in red. $136 \times 108 \mathrm{~mm}(300 \times 300 \mathrm{DPI})$ 